sures, the details of which will shortly be published, have led to the following conclusions in reference to the conditions necessary for the existence of any substance in the liquid state. These are two in number, viz. :-

I. In order to convert a gas into a liquid the temperature must be below a certain point (termed by Andrews the critical temperature of the substance), otherwise no amount of pressure is capable of liquefying the gas.

2. In order to convert a solid into a liquid the pressure must be above a certain point, which I propose to call the critical pressure of the substance, otherwise no amount of heat will melt the substance.

If the second of the above conditions be true, it follows that if the necessary temperature be attained, the liquefaction of the substance depends solely on the superincumbent pressure; so that if by any means we can keep the pressure on the substance below its critical pressure, no amount of heat will liquefy it, for in this case the solid substance passes directly into the state of gas, or in other words it sublimes without previous melting.

Having come to this conclusion, it was easily foreseen that if these ideas were correct it would be possible to have solid ice at temperatures far above the ordinary melting point. After several unsuccessful attempts, I was so fortunate as to attain the most perfect success, and have obtained solid ice at temperatures so high that it was impossible to touch it without burning one's self. This result has been obtained many times and with the greatest ease, and not only so, but on one occasion a small quantity of water has frozen in a glass vessel which was so hot that it could not be touched by the hand without burning it. I have had ice a considerable length of time at temperatures far above the ordinary boiling-point, and even then it only sublimed away without any previous melting. These results were obtained by maintaining the superincumbent pressure below $4^{\circ} \cdot 6 \mathrm{~mm}$. of mercury; i.e., the tension of aqueous vapour at the freezingpoint of water. Other substances also exhibit these same phenomena, the most notable of which is mercuric chloride, for which latter the pressure need only be reduced to about $420 \mathrm{~mm}$. On letting in the pressure the substance at once liquefies.

For the success of these experiments in the case of water one or two details of manipulation are necessary, but these will be subsequently described.

Firth College, Sheffield, September 6

\section{A Doubtful British Mollusk}

I HAve just observed that I am quoted in Dr. Gwyn Jeffreys' "British Conchology" (vol. v. p. I6I) as an authority for the discovery of Clausilia parvula (a Continental snail) in Staffordshire. Many years ago, when I was a schoolboy, I found six or seven specimens at Kinver, near Stourbridge. I took them at first for a smooth variety of $C$. rugosa, but noting other differences sent them to Dr. Jeffreys, who identified them as above. I never had another opportunity of visiting the spot, but brother conchologists, who went on my recommendation, failed to find any specimens. The sheep-walk on which I picked them up was close to the grounds of Enville, where there are many foreign shrubs, and I have now little doubt that they were introduced. At the same time the large size of the specimens seemed to indicate that they had been long acclimatised, as northern individuals are larger than southern.

Broad Street, Lyme Regis, Dorset

\section{A Halo}

MAX I mention a strange appearance which I saw in the heavens on August 29, and ask for an explanation of it? It was a rainbow without rain, and in the same quarter of the heavens as the sun.

At 5.45 p.m. I observed in a little nearly circular opening in the clouds, at the same height above the horizon as the sun, and about $23^{\circ}$ to the north of it, all the colours of the rainbow. They were very vivid, and lasted for several minutes. Two persons who were with me also saw this strange sight, which I cannot account for in any way. Was it seen by any of your readers? And what could be the cause of it ?

Brighton, September 2

[This was probably a portion of the ordinary halo of $22^{\circ}$. If so, it indicates the presence of ice-crystals (not of drops of water) in the upper atmosphere. Such things are common enough in autumn, especially when there is a sudden lowering of temperature by an anticyclone.-ED.]

\section{Tone of Violins}

I sAw a little time back, but omitted to note it at the time, a brief notice of some German experiments showing that the strings of good old instruments of fine tone tended far more than in the case of inferior violins to vibrate in closed curves or simple curves. I have searched NATURE in vain for some weeks, but cannot find it, though I thought it was in these columns. I am particularly anxious to recover it for purposes of my own connected with another branch of physics, and shall be obliged if any reader can refer me to the notice, or to the paper, or any translation of it.

LEWIS WRIGHT

Angust 30

\section{ADOLPH EDOUARD GRUBE}

BY the sudden death of Prof. Grube of Breslau on June 23, zoological science has been deprived of one of its enthusiastic and veteran cultivators. Born in Königsberg on May 12, I812, he entered the university of that city in 1831 , and graduated in medicine in 1837. Thereafter he became a private lecturer on zoology in Königsberg. In 1844 he was appointed to the Professorship of Zoology in the University of Dorpat, and lastly was transferred, in 1857 , to a similar post in the University of Breslau, where he laboured till his death.

He chose for the subject of his inaugural dissertation (in I837) the structure of Pleione carunculata, Pallas, and it is interesting that at this early age he selected one of the group in which his chief work in after-life was accomplished; for though he published various valuable researches in other departments (e.g., those on the Branchiopod Crustaceans), still the Annelida most benefited by his labours during the subsequent forty-three years. Moreover, he observed so carefully, as wellas laboured so industriously, that he was facile princeps in the department at his death. The bare enumeration indeed of his zoological works and papers is formidable ; and their perusal bears imperishable witness to the well-directed energy and great ability of their author. He himself, with great modesty, used to state that his work fell far short of that of the late M. Claparède, who, with a delicate physique, nevertheless accomplished a marvellous amount of valuable work, both with pen and pencil. But though perhaps less of an artist than the talented Swiss, the greater tenacity of constitution in the stalwart German, combined with his indomitable energy and perseverance throughout a longerlife, enabled him to overtake a much greater amount of work, especially in descriptive zoology.

The conscientious manner in which he carried on his scientific labours is well shown in his "Familien der Anneliden" (185I), a work which even now is of great value, and indispensable to workers in the department. The same may be said of his "Entwicklung der Anneliden" (1844) and his "Annulata Erstediana" (1857) In his original papers in the Archiv für Naturgeschichte and in the recent admirable series in the Sitzung der Schlesischen Gesellschaft, on the families of the Annelida, he demonstrated the encyclopædian and critical knowledge which he had of the whole group in a remarkable manner, just as his "Bemerkungen über Anneliden der Pariser Museums" showed his great experience in discriminating the species described by others. His last large publication (a work of $300 \mathrm{pp}$., 4to, and fifteen fine plates by his tried assistant Assman) is devoted to the numerous Philippine annelids collected by Prof. Semper, and is a lasting memorial of his accuracy and patient industry.

Nor was he a zoologist who confined his researches to a single group. He was an accomplished carcinologist, and his faunistic treatises, e.g., his "Actinien, Echinodermen u. Würmer des Adriatischen u. Mittelmeers," his "Ausflug nach Triest u. dem Quarnero," as well as his special papers on the Echinodermata, on Peripatus and other Arthropods, testify abundantly to the breadth 